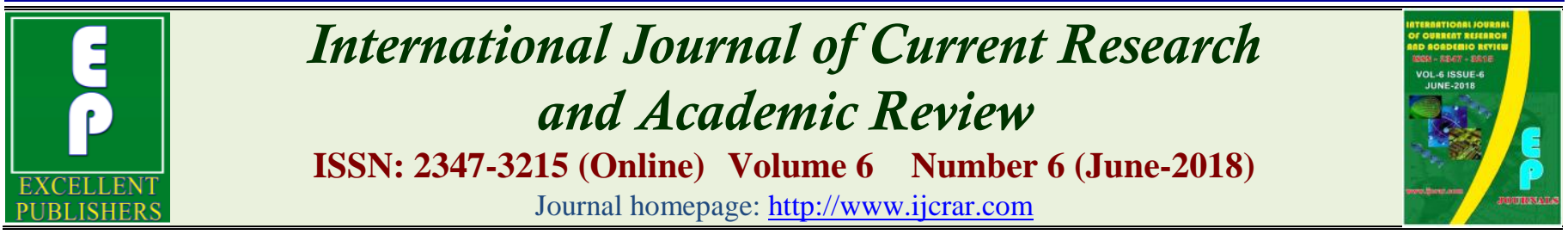

doi: https://doi.org/10.20546/ijcrar.2018.606.005

\title{
Interrelationships between Composition and Coagulation Properties of Milk from Bulgarian Murrah Buffaloes
}

\author{
Vladimir Karabashev ${ }^{1}$, Teodora Angelova ${ }^{1}$, Daniela Yordanova ${ }^{1}$, Georgi Kalaydzhiev, \\ Stayka Laleva ${ }^{1}$, Nikolay Oblakov ${ }^{2}$ and Zhivko Krastanov ${ }^{1 *}$ \\ ${ }^{1}$ Agricultural Institute Stara Zagora, Bulgaria \\ ${ }^{2}$ Freelance consultant, Bulgaria \\ *Corresponding author
}

\begin{abstract}
The purpose of the present study was to investigate the relationships between milk composition and milk coagulation properties in Bulgarian Murrah buffaloes. The study comprised data from analysis of milk samples from 476 Bulgarian Murrah buffaloes reared in three Bulgarian farms. The major part of buffaloes /194/ belonged to the class with RCT within the range 11.3-18 min, characterised with milk fat to protein ratio of $1: 1.23$. The tendency with respect to milk fat content showed that as milk fat increased, rennet coagulation time became shorted while curd firmness increased. The trend of milk protein confirmed that the effect of increased milk protein content was towards reduction of rennet coagulation time and increased curd firmness.
\end{abstract}

\section{Article Info}

Accepted: 28 May 2018

Available Online: 20 June 2018

\begin{tabular}{l} 
Keywords \\
\hline Bulgarian Murrah buffaloes, Buffalo milk, \\
Milk coagulation property (MCP), Curd \\
firming time (K20 min), Curd firmness (A30 \\
mm), Rennet coagulation time (RCT, min).
\end{tabular}

\section{Introduction}

Buffalo milk is distinguished with very high fat content that is on the average twice higher than fat in cow milk. The fat to protein ratio in buffalo milk is about 2:1. Compared to milk of cattle, buffalo milk has higher casein to protein ratio. The high content of calcium from casein facilitates the production of cheese /http://www.fao.org/.

The average annual milk yield of Bulgarian Murrah buffaloes is $1800-2000 \mathrm{~kg}$. Protein content of buffalo milk (Peeva, 2000) ranges within $3.6 \%$ and $5.7 \%$. The milk fat percentage in Bulgarian Murrah buffaloes varies from 7.1 to $9.8 \%$ (Peeva, 1997, 2000). The major part of buffalo milk produced in Bulgaria is processed into dairy products - cheeses, yogurt etc.
The coagulation properties of milk are essential for production of cheese (Aleandri et al., 1989; Wedholm et al., 2006; De Marchi et al., 2008). A number of researchers (Zicarelli et al., 2001; Potena et al., 2001a;b) have investigated the variability of parameters characterising milk composition and their relationships with milk coagulation properties in buffaloes reared in southern Italy.

Milk protein is the primary component for production of larger amounts of cheese. It has a definite effect on milk coagulation properties (Guinee, 2003). Gotet (2010) demonstrated a positive relationship between milk fat $\%$ and milk coagulation properties. This is opposite to data reported by Ostersen et al., (1997). 
Between January and March 2010, 200 animals from 5 herds reared in northern Italy were investigated to identify the factors influencing milk coagulation properties in Mediterranean buffaloes (Cecchinato et. al., 2012). According to the results, factors with significant effects for milk coagulation properties were the herd and $\mathrm{pH}$. Rennet coagulation time was influenced by days in lactation and fat and protein contents, while curd firmness - by milk casein content. The authors concluded that casein and $\mathrm{pH}$ could be used as tools for improvement of technological properties of buffalo milk.

According to De Marchi et al., (2008), Gotet (2010), Zicarelli et al., (2001) milk fat content did not have an effect on coagulation time.

So far, the studies at a national scale investigating the associations of milk composition and milk coagulation properties for cheese production are limited Karabashev (2016).

The purpose of the present study was to investigate the relationships between milk composition and milk coagulation properties in Bulgarian Murrah buffaloes.

\section{Materials and Methods}

The study comprised data from analysis of milk samples from 476 Bulgarian Murrah buffaloes reared in three Bulgarian farms - in Gorna Rositsa, Lozenets and Makak settlements.

Individual milk samples $(50 \mathrm{~mL})$ were collected during the morning milking without adding preservatives. Samples were stored in cooling bags at $4{ }^{\circ} \mathrm{C}$. Within 3 hours from collection, they have been transported to the lab of the Agricultural Institute - Stara Zagora.

Individual milk coagulation properties were determined by means of Computerized Renneting Metter - Polo Trade, Italy. Ten $\mathrm{mL}$ of milk from each individual sample were heated to $35{ }^{\circ} \mathrm{C}$, and afterwards, $0.2 \mathrm{~mL}$ chymosin (NATUREN Plus 215/0,8 1) were added. Individual milk coagulation property (MCP) was measured within $30 \mathrm{~min}$ after rennet addition. The parameters characterising MCP were: rennet coagulation time (RCT, min); curd firming time (K20 min) и curd firmness $(\mathrm{A} 30 \mathrm{~mm})$.

Milk composition: milk fat $\%$, and milk protein $\%$ were assayed with Ekomilk Total ultrasonic milk analyzer ISO 9001:2000.
For unbiased evaluation of studied factors, the BLUP test day animal model was applied.

The following mixed linear model was used:

\section{Yijklmn $=\operatorname{tr}_{\mathrm{i}}+$ HYM $_{\mathrm{j}}+$ Age $_{\mathrm{k}}+$ Testdim $_{\mathrm{l}}+$ Animal $_{\mathrm{m}}+$ eijklm $_{n}$}

where:

$\operatorname{tr}_{\mathrm{i}}-$ main fixed effect of the $\mathrm{i}^{\text {th }}$ protein or fat percentage in milk; for establishment of the effect of milk composition on its coagulation properties, with ten classes according to milk fat percentage: $2.0 \leq 2.99$; $3.0 \leq 3.99 ; 4.0 \leq 4.99 ; 5.0 \leq 5.99 .6 .0 \leq 6.99 ; 7.0 \leq$ $7.99 ; 8.0 \leq 8.99 ; 9.0 \leq 9.99 ; 10.0 \leq 11.0 ; \geq 11.00$, and six classes with respect to milk protein content: $2.0 \leq$ $2.99 ; 3.0 \leq 3.99 ; 4.0 \leq 4.99 ; 5.0 \leq 5.99 ; 6.0 \leq 6.99 ; \geq$ 7.0 .

$\mathbf{H Y} \mathbf{M}_{\mathbf{j}}$ - fixed effect of the $\mathrm{j}^{\text {th }}$ herd-year-month of sampling;

Age $_{\mathbf{k}}$ - regression effect of age (in days) by the test day date;

Testdim $_{1}$ - regression effect of days in milk by the test day date during the respective lactation;

Animal $_{m}$ - random effect of the $m^{\text {th }}$ animal;

$\mathbf{e}_{\mathrm{ijklmn}}-$ random effect of unobserved factors

Data analysis was done with the Pest /Groeneveld/ software.

\section{Results and Discussions}

The results from Table 1 show that milk fat percentage ranged within $6.72 \%$ and $7.14 \%$ for the different RCT classes. Milk protein range was $4.76 \%-5.34 \%$. Standard deviations of milk fat content $/ 0.94-1.59 /$ were higher than those of milk protein $/ 0.46-1.15 /$. Coefficients of variation of both traits exhibited the same tendency: they were higher $/ 0.14-0.23 /$ for milk fat and $0.09-0.24$ for milk protein. The highest milk fat percentage was established for milk with RCT between 10.3-11.3 min (7.14\%), while the lowest milk fat was that of milk with RCT 11.3- 18.0 min (6.60\%). This result was found in the highest number of analysed samples -194 . The next class with respect to RCT (6.00 to $10.3 \mathrm{~min}$ ) comprised a significant number of buffaloes - 114 , whereas in the other classes, the number of animals was from 6 to 41 . It should be noted that all curd firmness values varied within a narrow range from 33.2 and $33.8 \mathrm{~mm}$, except for the class with the shortest RCT $/ 6.00 \mathrm{~min} /$, where the 
curd firmness was logically relatively high $(35.1 \mathrm{~mm})$, as well as for the class with highest RCT /26-30 min/, where curd firmness was expectedly $15.3 \mathrm{~mm}$, indicating a loose coagulum. The number of animals in these classes was 41 and 38 respectively - a relatively low proportion from the total number of studied buffaloes.

Table.1 Arithmetic mean, standard error of the mean and coefficient of variation of milk fat and milk protein percentages depending on rennet coagulation time

\begin{tabular}{|c|c|c|c|c|c|c|c|c|c|}
\hline \multirow{2}{*}{$\begin{array}{c}\text { RCT } \\
\min \end{array}$} & \multirow{2}{*}{$\begin{array}{c}N \\
476\end{array}$} & \multirow[t]{2}{*}{ A30 } & \multicolumn{3}{|c|}{ Fat \% } & \multicolumn{3}{|c|}{ Protein \% } & \multirow[t]{2}{*}{ Fat/Protein } \\
\hline & & & Mean \pm SE & SD & $\mathbf{C V}$ & Mean \pm SE & SD & $\mathbf{C V}$ & \\
\hline$<6.00$ & 41 & 35.1 & $6.72 \pm 0.25$ & 1.59 & 0.23 & $5.22 \pm 0.13$ & 0.82 & 0.16 & $1: 1.29$ \\
\hline $6.00-10.3$ & 114 & 33.7 & $6.88 \pm 0.12$ & 1.30 & 0.19 & $5.02 \pm 0.06$ & 0.64 & 0.13 & $1: 1.38$ \\
\hline $10.3-11.3$ & 35 & 32.2 & $7.14 \pm 0.20$ & 1.16 & 0.16 & $5.02 \pm 0.08$ & 0.49 & 0.10 & $1: 1.42$ \\
\hline $11.3-18.00$ & 194 & 33.2 & $6.60 \pm 0.10$ & 1.45 & 0.22 & $5.34 \pm 0.06$ & 0.80 & 0.15 & $1: 1.23$ \\
\hline $18.00-19.00$ & 11 & 33.4 & $6.75 \pm 0.28$ & 0.94 & 0.14 & $4.76 \pm 0.35$ & 1.15 & 0.24 & $1: 1.41$ \\
\hline $19.00-25.00$ & 37 & 33.6 & $6.79 \pm 0.18$ & 1.07 & 0.16 & $5.26 \pm 0.09$ & 0.55 & 0.10 & $1: 1.30$ \\
\hline $25.00-26.00$ & 6 & 33.8 & $6.99 \pm 0.41$ & 1.10 & 0.14 & $5.01 \pm 0.18$ & 0.46 & 0.09 & $1: 1.39$ \\
\hline $26.00-30.00$ & 38 & 15.3 & $6.93 \pm 0.26$ & 1.59 & 0.23 & $5.04 \pm 0.16$ & 0.96 & 0.19 & $1: 1.38$ \\
\hline
\end{tabular}

Fig. 1. Distribution of milk samples according to their RCT

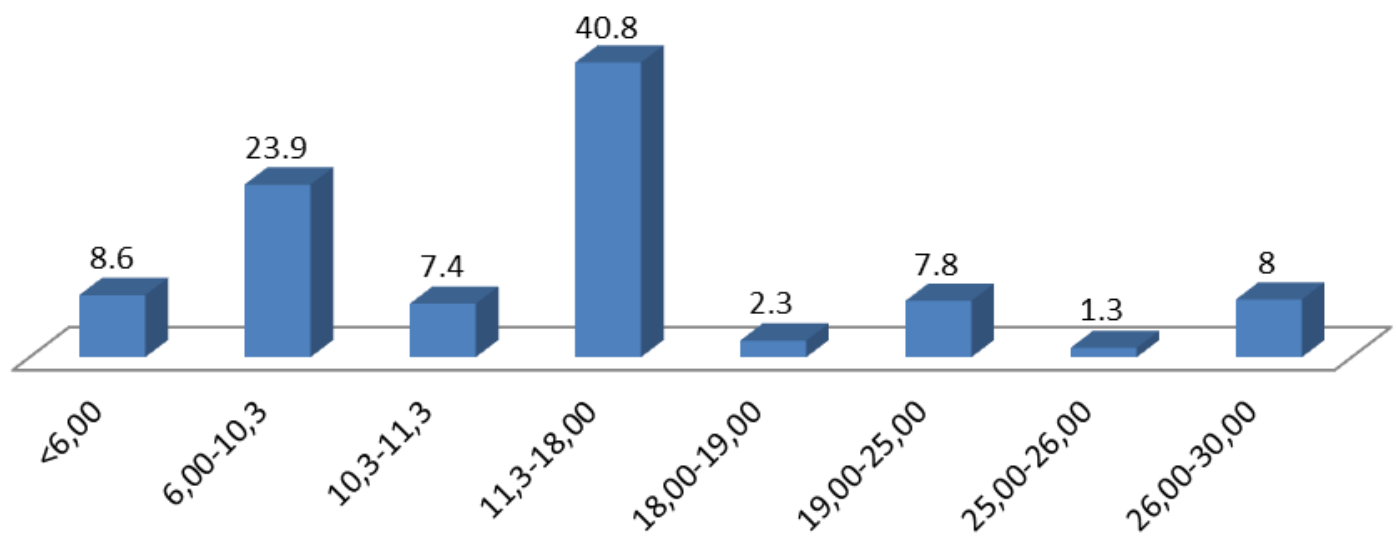



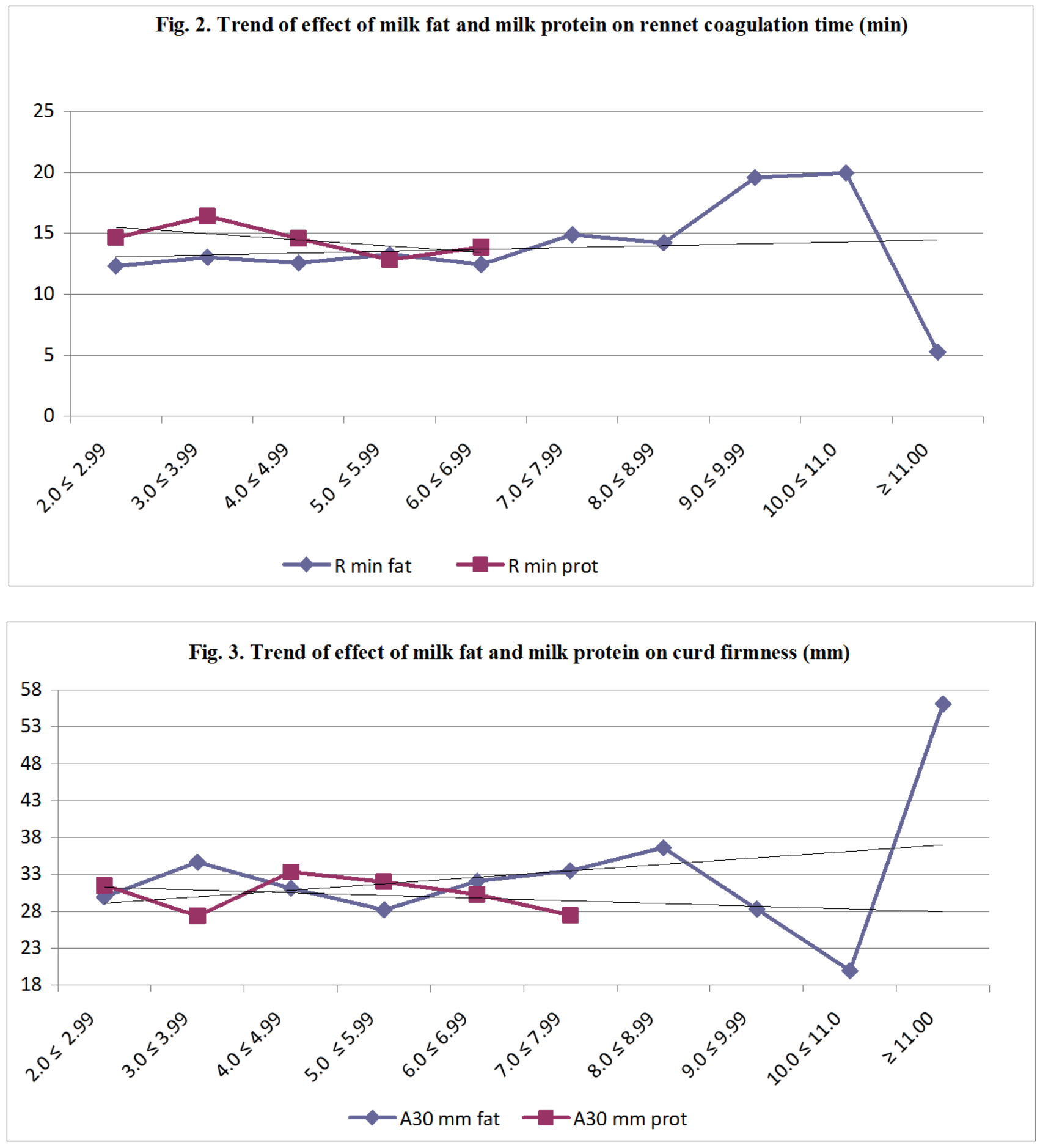

Peeva $(1997,2000)$ reported higher milk fat content from 7.1 to $9.8 \%$. Milk protein was the highest in milk coagulating within 11.3 and $18.0 \mathrm{~min}(5.34 \%)$, whereas milk with RCT from 18 to 19 min exhibited the lowest milk protein percentage $(4.76 \%)$. A research on 161 lactating buffaloes reared in Sicily (Liotta et al., 2015) found out that produced milk had lower protein content than that in our study $-4.61 \%$.
Milk with RCT of 10.3 to $11.3 \mathrm{~min}$ had the highest ratio of quality traits - fat $\%$ and protein $\% / 1: 1.42 /$, while the lowest ratio $1: 1.29$ was observed in milk with shorter $\mathrm{RCT}$ - up to $6 \mathrm{~min}$.

The highest proportion of buffaloes $(40.8 \%)$ produced milk with RCT in the interval from 11.3 to 18 min (Fig. 1). In general, the major part of milk samples had RCT 
up to $18.00 \mathrm{~min}-80.7 \%$, while $19.3 \%$ needed more time to form a coagulum - from 18 to $30 \mathrm{~min}$.

Fig. 2 presents the trend of effect of milk fat and milk protein percentages on rennet coagulation time (RCT, min). The shortest RCT (5.27 min) was determined for milk fat $\geq 11 \%$, while longest RCT (19.92 min) was exhibited by milk with fat content between $10.0 \leq$ $11.00 \%$. A similar tendency was established by Liotta $e t$ al., (2015) - the milk with higher fat percentage (8.78\%) had longer RCT $(21.3 \mathrm{~min})$ in disagreement with Cecchinato et al., (2013) who outlined that increase in milk fat \% from 6.71 to $9.05 \%$ was accompanied by shorter RCT - from $11.05 \mathrm{~min}$ to $13.95 \mathrm{~min}$.

Milk protein - the primary component for cheese production, had en effect on all traits characterising milk coagulation properties (Guinee, 2003). The shortest RCT (12.84 min) was found out in milk whose protein content was from 5.00 to $5.99 \%$ while the highest RCT of 16.04 min was observed in milk with protein content between 3.00 and $3.99 \%$. The tendency was to shorter coagulation times parallelly to increase in milk protein, which was most probably due to the higher casein content. This relationship was in line with the results of Guinee (2003) affirming that RCT decreased along with increase in milk protein.

The other studied parameter - curd firmness (Fig. 3) had the lowest value $(19.97 \mathrm{~mm})$ when milk fat ranged from 10 and $11 \%$, whereas highest curd firmness $(56.06 \mathrm{~mm})$ was observed with milk fat over $11 \%$.

The demonstrated trend confirmed that curd firmness increased proportionally to milk fat percentage. These results agreed with those reported by Aleandri et al., (1989) and Guinee (2003), showing that the higher the milk fat, the higher the curd firmness was.

The highest curd firmness value $(33.31 \mathrm{~mm})$ was established for milk with protein content from 4.00 to 4.99\%). Liotta et al. (2015) showed that the milk produced by buffaloes reared in intensive production systems had better technological properties that the milk of buffaloes reared in semi-intensive systems. The milk of animals from intensive farms had higher curd firmness $-32.69 \mathrm{~mm}$ and higher protein content $-4.61 \%$.

\section{Conclusions and recommendations}

1. The major part of buffaloes /194/ belonged to the class with RCT within the range 11.3-18 min, characterised with milk fat to protein ratio of $1: 1.23$;

2. The tendency with respect to milk fat content showed that as milk fat increased, rennet coagulation time became shorted while curd firmness increased.

3. The trend of milk protein confirmed that the effect of increased milk protein content was towards reduction of rennet coagulation time and increased curd firmness.

\section{References}

Aleandri, R., Schneider, J.C., Buttazzoni, L.G. (1989). Evaluation of milk for cheese production based on milk characteristics and Formagraph measures. $J$. Dairy Sci., 72. 1967-1975. ANASB. (2009).

Cecchinato A, Penasa M, Gotet CC, De Marchi M, Bittante G. 2012. Short communication: Factors affecting coagulation properties of Mediterranean buffalo milk. J. Dairy Sci. 2012 Apr;95(4):170913. doi: 10.3168/jds.2011-4694.

Cecchinato, A., C. Cipolat-Gortet, J. Casellas, M. Penasa, A. Rossoni and G. Bittante, 2013. Genetic analysis of rennet coagulation time,curd-firming rate, and curd firmness assessed over an extended testing period using mechanical and near-infrared instruments. J.Dairy Sci. 96: 50-62.

De Marchi, M., Bittante, G., Dal Zotto, R., Dalvit, C., Cassandro, M. (2008). Effect of Holstein Friesian and Brown Swiss breeds on quality of milk and cheese. J. Dairy Sci., 91. 4092-4102.

Gotet, C., N. Cologna, M. De Marchi, A. Cecchinato, M. Penasa, G. Bittante, 2010. Preliminary characterization of coagulation properties of buffalo milk inVeneto region. Acta Agr. Kapos. 14:173-178.

Guinee T.P. 2003. Role of protein in cheese and cheese products. In P.F. Fox and P.L.H. McSweeney (eds.): Advanced Dairy Chemistry 1: Proteins, Part B, 3rd ed. Kluver Academic/Plenum Publisher, 2003. P. 1083-1174.

Hyldig, G. 1993. Rennet coagulation. Effect of technological parameters on the enzymatic reaction and gel formation in milk and UF concentrates. $\mathrm{PhD}$ thesis, Copenhagen: Royal Veterinary and Agricultural University.

Ikonen, T., M. Ojala, and O. Ruottinen. $1999 \mathrm{~b}$. Association between milk protein polymorphism and first lactation milk production traits in Finnish Ayrshire cows. J. Dairy Sci. 82:1026-1033. 
Liotta L., V. Chiofalo, V.Presti, A. Vassallo, G. Dalfino \& A. Zumbo, 2015. The Influence of Two Different Breeding Systems on Quality and Clotting Properties of Milk from Dairy Buffaloes Reared in Sicily (Italy). Italian Journal of Animal Science, 14:3, 3669

Karabashev, V., 2016. Genetic and environmental factors on milk production and individual coagulation ability of milk of buffalo race BULGARIAN MURRA PhD dissertation.

Ostersen, S., J. Foldager, J.E. Hermansen, 1997. Effects of stage of lactation, milk protein genotype and body condition at calving on protein composition and renneting properties of bovine milk. Journal of Dairy Research, 64, 207-219.

Peeva, Tz., 1997. Composition of buffalo milk. 1. Correlation between component and effect of some factors on them. $5^{\text {th }}$ World Buffalo Congress, pp. 13-16, October, Caserta, Italy, pp. 217-220.

Peeva, Tz., 2000. Optimized methods of selection in buffaloes. Dr. Agric. Sci. Thesis., Agricultural Institute, Shoumen, pp. 320.

\section{How to cite this article:}

Vladimir Karabashev, Teodora Angelova, Daniela Yordanova, Georgi Kalaydzhiev, Stayka Laleva, Nikolay Oblakov and Zhivko Krastanov. 2018. Interrelationships between Composition and Coagulation Properties of Milk from Bulgarian Murrah Buffaloes. Int.J.Curr.Res.Aca.Rev. 6(6), 43-48.

doi: https://doi.org/10.20546/ijcrar.2018.606.005
Potena, A., Bove, D., Cocca, T., Zicarelli, L. (2001a). Andamento di alcuni componenti del latte di bufala in funzione della distanza dal parto: risultati preliminari. I. Cong. Naz. sull'allevamento del bufalo, 3-5/10/2001, Az. Ag. Improsta Eboli. 231- 235.

Potena, A., De Filippo, C., Bove, D., Cocca, T., Haubner, T., Zicarelli, L. (2001b). Resa alla caseificazione e parametri reologici del latte bufalino: risultati preliminari su latti individuali. $I$. Cong. Naz. sull'allevamento del bufalo, 3.5/10/2001, Az. Ag. Improsta Eboli. 236-240

Wedholm, A., L.B. Larsen, L. H.indmark-Månsson, A.H. Karlsson, A. Andrén, 2006. Effect of protein composition on the cheese-making properties of milk from individual dairy cows. J. Dairy Sci., 89. 3296-3305

Ziccarelli, L. (2004). Buffalo Milk: Its Properties, Dairy Yield and Mozzarella Production. Veterinary Research Communications. 28. 127-135. 